Revista de la red interuniversitaria de estudios sobre las literaturas rioplatenses contemporáneas en Francia

13 | 2015

Nuevas experiencias editoriales y literaturas

contemporáneas

\title{
Postales de Oxirrinco
}

\section{Luis Chitarroni}

\section{OpenEdition}

Journals

Edición electrónica

URL: http://journals.openedition.org/lirico/2178

DOI: $10.4000 /$ lirico. 2178

ISSN: 2262-8339

\section{Editor}

Réseau interuniversitaire d'étude des littératures contemporaines du Río de la Plata

Referencia electrónica

Luis Chitarroni, «Postales de Oxirrinco », Cuadernos LIRICO [En línea], 13 | 2015, Puesto en línea el 15 diciembre 2015, consultado el 21 abril 2019. URL : http://journals.openedition.org/lirico/2178 ; DOI : 10.4000/lirico. 2178

Este documento fue generado automáticamente el 21 abril 2019.

\section{(c) (i) (2) $\Theta$}

Cuadernos LIRICO está distribuido bajo una Licencia Creative Commons Atribución-NoComercialSinDerivar 4.0 Internacional. 


\title{
Postales de Oxirrinco
}

\author{
Luis Chitarroni
}

La observación de VN acerca de la relación directa entre la confección del aforismo y el endurecimiento arterial no es descarnada ; y no es que la sabiduría y la juventud sean antagónicas, para nada. Hay una beatitud que condesciende a cierta expectativa sintáctica. Hay una sintaxis sentenciosa, reverente del apotegma y la cláusula asertiva [apodíctica]. Se adecua mejor a cierta morosidad algebraica que a la velocidad rapsódica, digamos, inobjetable de Rimbaud.

Prometo cambiar de ejemplos la próxima vez.

Concedida la gracia - $i$ o venia ?- de abstenernos, escribiremos igual con el afán de librarnos de ella, de perderla.

Pieles y pieles y pieles $<\mathrm{y}$ huellas>. Texturas. Pesadas pieles de osos, bueyes almizcleros, martas cibelinas en alud. A eso llamo desde mi cama -proxenia ideal, nada paradójicami contacto deseado con el mundo.

Pereza. Bazlen. Dibujo sin gracia en la almohada. Dibujo de un cráter y una cueva, bien diferenciados. Cuevacaviar. En uno y en otra entra Bazlen el tejón cuando se despierta. Balzac. Sin curiosidad, hastiado. Y la forma que dejó su cabeza en la almohada se consolida. Mancha.

Bloy. Toulet. Péguy. Mis gustos franceses, hoy tan desplazados.

Escribo porque dibujo y viceversa. Escribo porque arranco, porque no tengo idea. Escribo y dibujo y viceversa. Hasta inversamente me corresponde disculparme.

Creo que no hay modo de escribir si no se dibuja. Cierto que la figura triunfante de hoy es el impostor.

Inicialmente, y por las Lomo, <la> acumulación de latas de sardinas. Epitaph for a thimble. Otros objetos dignos de yacer en estas sepulturas [Standard: ] broches, lápices, sacapuntas, insectos, mariposas, semillas, fósforos, cenizas, uñas. Piolines. Cascarria variopinta. Cultivo de polvo.

Photographism, Truth. Struth 
¿Y si escribiera abismo así : avismo?

Benjamin Lee Whorf. Tiempos en los que Chomsky era lingüista. No nada más, claro.

Líricas de distinto peso : Michaux, por ejemplo, y Desnos. Rodajas de Chateaubriand, Saint-Simon, Saint-John Perse. Retóricas, consistencias disímiles, de ninguna manera susceptibles a las técnicas de Burroughs, que no tiene, como buen hijo de una familia dedicada a calcular. Idea del peso, real o específico.

Noticia sobre Burroughs Seward real.

Informe de Gil de Biedma sobre la empresa tabacalera de sus antepasados en Filipinas.

La verdad en su vuelco concupiscente menos justificado. (San) Agustín (de Hipona), Kafka de Praga, Leiris de París, Landolfi de Pico ().

Concedida la gracia de abastecernos, hacer caso omiso.

[repetida] Águeda o Fátima me piden

Justina (la pícara), Margarita

Elena, Teodelina

Leer lo breve con insatisfacción, como corresponde. Ligereza de planos, más que de conceptos.

[Menos que de conceptos, ligereza de planos.]

Si tuviera hoy que elegir un animal...

Elegiría el jabato de Hans Hoffman, de ternura tan obtusa. Glory be to God for dappled things (GMH). Y estoy seguro de que me saldría mal.

La brevedad es un mal.

Putrefacción. Entre Cioran y Wallace Stevens, a quienes hace tanto que no leo.

Qué convocatoria. ¡ Qué convicción!

Sí, dejar pasar, atenuar, disuadir, olvidar. Todo un proyecto de abandono.

Avíos, atavismos.

Otros : lentejas, garbanzos, legumbres en general. Granos de arroz. Cuentas de rosario. Bolitas japonesas. Fondos, graznidos. Maneras de integrarlos.

Maneras de atentar contra la materia también, ya que no contra el materialismo. Questa piccola reliquia... ¿ Estampitas? ¿Cómo taparlas?

El penitente por falta de talento. Envidia inmóvil, ascendente.

Y Basho : metáforas ascendentes y descendentes. Élitros, estridor. Alas de libélula.

Fábrica de sardinas Nagara.

Un mal de fábrica.

Una vez resuelto el problema ( ¿ es un problema?) de los materiales, hay que desdeñar el problema ( $i$ es un problema ?) de las imágenes. ¿ De las mutaciones?

Tema de las mutaciones del mar (John Peale Bishop). ¿ Ilustrar?

Cuentas de glosario. 
Sor Filotea

Mutación (Peale Bishop), mutabilidad (Spenser)

Sílabas, amígdalas, bosquimanos.

Frascos/recipientes : alcaparras, nutella, azafrán, lentamente, exotic<c>ans

Por un hechizo filosófico arquitectónico podríamos convertir las mónadas en ventanas.

Libertad a los presocráticos

Y así y más : me desperté y no era otro día. Suele notarse porque Heráclito sucedió a Hesíodo para criticarlo y hacer efectiva la indiferencia. El sueño y la vigilia están a mano, como la noche y el día. Si de veras fuéramos dioses : nuestros sueños serían como la vigilia de ustedes.

El sueño, ese primer sueño que relata o refiere la nota -soy mejor para los detalles, cualquiera se habrá dado cuenta, que para los conceptos generales- ocurría en una especie de gruta, de sistema o bosque de rincones, como el de la sesión de fotografía de Five Leaves Left, el primer album de Nick Drake. Será difícil volver a la orilla.

\section{AUTOR}

LUIS CHITARRONI

Escritor 